\title{
Pollen resources used by Chrysoperla agilis (Neuroptera: Chrysopidae) in the Azores, Portugal
}

\author{
Leila NUNES MORGADO, Roberto RESENDES, Mónica MOURA and Maria A. MATEUS VENTURA
}

CIBIO, Centro de Investigação em Biodiversidade e Recursos Genéticos, InBIO Laboratório Associado, Pólo Açores, Departamento de Biologia, Universidade dos Açores, Rua da Mãe de Deus, Apartado 1422, 9501-801, Ponta Delgada, Açores, Portugal, e-mails: leilamorgado@uac.pt; roberesendes@uac.pt; moura@uac.pt; mateus@uac.pt

Key words. Neuroptera, Chrysopidae, Chrysoperla agilis, beneficial insect, Azores Archipelago, foraging behavior, palynology, trophic resources

\begin{abstract}
There are approximately 1200 described species of Chrysopidae, many of which are predators of agricultural pests. Species of Chrysoperla are mass-produced and sold for use as biological control agents of agricultural pests in Europe, Asia, North and South America. Chrysoperla agilis, a member of the "carnea group" of Chrysoperla, has the potential to be biocontrol agent and is native to the Azores, and therefore a local candidate for use in IPM of pests, such as aphids and scale insects. Given that many adult Chrysopidae feed on pollen and honeydew and the biology of Ch. agilis is not well understood, we studied the preferences of $C h$. agilis adults living in a greenhouse on the campus of the University of the Azores for feeding on different types of pollen. Twenty-six species of flowering plants, belonging to 16 families and 24 genera, all previously recorded on São Miguel Island, were found in the greenhouse. Pollen grains from each species were collected and incorporated in a reference catalogue. Additionally, 40 adults of Ch. agilis were collected (20 in December 2012 and 20 in January 2013) and the pollen in guts identified. Of the 26 species of plants in the greenhouse 14 were used as sources of pollen by the lacewings. Pollen of Plantago lanceolata L. was the most frequently recorded pollen in the gut contents. The adults of this chrysopid fed mainly on the pollen of species of plants belonging to the Asteraceae, Plantaginaceae and Poaceae. The species richness $(\mathrm{S}=12)$, diversity index $\left(\mathrm{H}^{\prime}=2.123\right)$ and equitability $\left(\mathrm{J}^{\prime}=\right.$ 0.8543 ) of the January sample are greater than those of the December sample. Similarity of the samples collected in the 2 months was 0.75 . From these results we infer that it is important to maintain or increase plant biodiversity in agroecosystems as weeds provide trophic resources for insects that are beneficial to agriculture.
\end{abstract}

\section{INTRODUCTION}

The Neuroptera include approximately 6000 described species allocated among 17 families. Many of them are predators of agricultural pests. Lacewings can be found in all major biogeographic regions of the planet (Aspöck et al., 2001). Adults and larvae of most neuropteran families are predators and some species are used as natural enemies in biological control programs (New, 2001). Species of Chrysopidae, Coniopterygidae and Hemerobiidae show the greatest potential for use in pest management in agricultural ecosystems (Stelzl \& Devetak, 1999). The Chrysopidae contain around 1200 species belonging to 80 genera and 11 subgenera in 3 subfamilies, the Apochrysinae, Chrysopinae and Nothochrysinae (Brooks \& Barnard, 1990; Freitas \& Penny, 2001).

Some species of Chrysoperla are mass-produced commercially for shipment and release as biological agents for controlling agricultural pests in Europe, Asia and North and South America (Carvalho \& Souza, 2000). Chrysoperla agilis (Henry et al., 2003) occurs naturally in the Azores islands (Ventura et al., 2005) and may be a useful part of integrated pest management programs (IPM) of several agricultural pests such as aphids and scale insects (Mendes \& Ventura, 2010).

Most species of lacewings are entomophagous in the larval stage, whereas in the adult stage many species feed primarily on plant substances such as nectar and pollen, and on animal products such as honeydew produced by aphids (Stelzl, 1991; Bozsik, 1992). A great diversity of plants promotes an abundance of lacewings by providing conditions for reproduction, protection and foraging (Stelzl \& Devetak, 1999; Landis et al., 2000; Gurr et al., 2003).
Here we report the results of a study of the pollen preferences in Chrysoperla agilis adults collected from a greenhouse in which several plant species commonly found in the Azores islands were present, most of them weeds.

\section{MATERIAL AND METHODS}

Our research was done in a greenhouse on the premises of the Universidade dos Açores in Ponta Delgada, during the months of December 2012 and January 2013. The different flowering plants were distributed in a more or less random way in the greenhouse and produced pollen throughout this study. Plants were catalogued and found to include 26 species in 24 genera and 16 families, all of them herbaceous and known to occur on the island of São Miguel. Among these species, three are grown for food and were dominant in the greenhouse - pumpkin (Cucurbita maxima Duch.), tomato (Solanum lycopersicum L.) and spinach (Tetragonia tetragonioides Pall. Kuntze).

Flowers and flower buds in pre-anthesis were collected from each species, so that pollen grains could be removed and subjected to acetolysis, according to Erdman (1952). Three slides were prepared of each species' pollen and were used as a pollen reference catalogue of the plants present in the greenhouse. Pollen analysis was performed using a light microscope.

Forty Ch. agilis adults were collected in two groups of 20 individuals (one group for each of the two months sampled), and the gut contents of each group were pooled for analysis. The insects were killed by freezing $\left(-80^{\circ} \mathrm{C}\right)$ and their gut contents were removed using forceps and a probe, and macerated in a centrifuge tube, after which acetic acid was added. After fortyeight hours, the samples were centrifuged and the supernatant 
discarded. The sample was then treated by acetolysis according to Erdman (1952). Four slides were prepared for each sampling period. Counting and identification of pollen grains was performed using a light microscope. Identified pollen types were photomicrographed.

Evaluations were based on the total counts of pollen grains recorded on the slides ( 4 slides per month). Pollen types were grouped into 4 classes of relative frequency (Zander, 1935): dominant (over $45 \%$ ), accessory ( $15 \%$ to $44 \%$ ), important isolated pollen ( $3 \%$ to $14 \%$ ) and occasional isolated pollen (under $3 \%$ ). The terminology employed for pollen characterization is based on the glossary of Punt et al. (2007).

Statistical analysis was carried out using PAST - Palaeontological Statistics (Hammer et al., 2010). Diversity estimates of ingested pollen were calculated using the following indices: Diversity (Shannon-Wiener H'), Equitability (Pielou J'), Similarity (Simpson C) and Specific Richness (S) (Magurran, 2004).

The collection of pollen grain slides was deposited in the Departamento de Biologia - Universidade dos Açores, Ponta Delgada.

\section{RESULTS}

Of the 26 species of herbaceous plants flowering in the greenhouse Chrysoperla agilis fed on the pollen of 14. In the December sample, the pollen of Plantago lanceolata L. (Plantaginaceae) (Table 1), which is common in the Azores, was the most consumed and dominant (over 45\%) in terms of the different types of pollen found in the guts of the lacewings. In January, the pollen grains of this species were less frequently recorded, but nonetheless it was the most frequently recorded (Table 1) and classified as accessory pollen (15\% to 44\%).

In the December sample, Eleusine indica (L.) Gaertn. (Poaceae) was the only type of pollen classified as accessory, with that of the other species classified as occasional isolated pollen (under 3\%). In the January sample, the pollen grains of Nicandra physalodes (L.) Gaertn., Oxalis corymbosa DC., Rumex crispus L., Solanum lycopersicum L., Poa annua L., Cyperus rotundus L., Bidens pilosa L., Chenopodium murale L., Amaranthus blitum L. and Sonchus oleraceus L., were classified as important isolated pollen ( $3 \%$ to $14 \%$ ) (Table 1$)$.

The pollen of Ch. murale, Erigeron karvinskianus DC. (Asteraceae), C. rotundus, $P$. lanceolata, $R$. crispus and $S$. lycopersicum was used by lacewings in both months, but in different percentages in each month (Table 1, Fig. 1).

The plant families that included the most preferred species for the lacewings in both months were Asteraceae, Plantaginaceae and Poaceae (Table 1). When compared to the December sample, there was a greater richness, higher diversity index and higher equitability of types of pollen in the January sample. Similarity of the types of pollen recorded in the gut contents in the two months was high, indicating that the preference of the lacewing for certain species of plants did not change between months (Table 1).

\section{DISCUSSION AND CONCLUSION}

Agricultural ecosystems with a diversified flora and, consequently, a diversified pollen grain pool, may better promote the control of pests through greater predator efficiency (Venzon et al., 2006). Fitness of adult Chrysopidae depends on imaginal nourishment and pollen provides them with the nutrients necessary for oviposition (fertility) (Sundby, 1967). Chrysoperla agilis adults showed a marked preference for the pollen of $P$. lanceolata, commonly known as lamb's tongue. In the Azores, this plant has become naturalized and can be found at different altitudes, especially in pastures and along the edges of culti-
TABLE 1. Composition of the flora in the greenhouse and the abundance $(\mathrm{Ab})$ and relative frequency $(\mathrm{fr} \%)$ of the different pollen grains fed on by adults of Chrysoperla agilis Henry et al. 2003 (Neuroptera: Chrysopidae).

\begin{tabular}{|c|c|c|c|c|}
\hline \multirow{2}{*}{ Taxa } & \multicolumn{2}{|c|}{ Dec/2012 } & \multicolumn{2}{|c|}{$\operatorname{Jan} / 2013$} \\
\hline & $\mathrm{Ab}$ & $\mathrm{fr} \%$ & $\mathrm{Ab}$ & $\mathrm{fr} \%$ \\
\hline \multicolumn{5}{|l|}{ AIZOACEAE } \\
\hline Tetragonia tetragonioides (Pall.) Kuntze & 00 & 00 & 00 & 00 \\
\hline \multicolumn{5}{|l|}{ AMARANTHACEAE } \\
\hline Amaranthus blitum $\mathrm{L}$. & 00 & 00 & 11 & 4.17 \\
\hline Chenopodium murale L. & 02 & 0.93 & 12 & 4.55 \\
\hline \multicolumn{5}{|l|}{ Asteraceae } \\
\hline Bidens pilosa $\mathrm{L}$. & 00 & 00 & 13 & 4.92 \\
\hline Erigeron karvinskianus DC. & 01 & 0.46 & 06 & 2.27 \\
\hline Sonchus oleraceus $\mathrm{L}$. & 00 & 00 & 08 & 3.03 \\
\hline \multicolumn{5}{|l|}{ BRASSICACEAE } \\
\hline Coronopus didymus (L.) Sm. & 00 & 00 & 00 & 00 \\
\hline \multicolumn{5}{|l|}{ CYPERACEAE } \\
\hline Cyperus rotundus $\mathrm{L}$. & 05 & 2.31 & 14 & 5.30 \\
\hline \multicolumn{5}{|l|}{ Cucurbitaceae } \\
\hline Cucurbita maxima Duch. & 00 & 00 & 00 & 00 \\
\hline \multicolumn{5}{|l|}{ EUPHORBIACEAE } \\
\hline Euphorbia peplus L. & 00 & 00 & 00 & 00 \\
\hline Mercurialis anпиа $\mathrm{L}$. & 00 & 00 & 00 & 00 \\
\hline \multicolumn{5}{|l|}{ LAMIACEAE } \\
\hline Stachys arvensis L. & 00 & 00 & 00 & 00 \\
\hline \multicolumn{5}{|l|}{ OXALIDACEAE } \\
\hline Oxalis corymbosa DC. & 00 & 00 & 22 & 8.33 \\
\hline \multicolumn{5}{|l|}{ PAPAVERACEAE } \\
\hline Chelidonium majus L. & 00 & 00 & 00 & 00 \\
\hline Fumaria muralis Sond. ex. Koch & 00 & 00 & 00 & 00 \\
\hline \multicolumn{5}{|l|}{ Phyllanthaceae } \\
\hline Phyllanthus tenellus Roxb. & 00 & 00 & 00 & 00 \\
\hline \multicolumn{5}{|l|}{ Plantaginaceae } \\
\hline Plantago lanceolata $\mathrm{L}$. & 156 & 72.22 & 96 & 36.36 \\
\hline \multicolumn{5}{|l|}{ Poaceae } \\
\hline Eleusine indica (L.) Gaertn. & 40 & 18.59 & 00 & 00 \\
\hline Holcus lanatus L. & 06 & 2.78 & 00 & 00 \\
\hline Poa annua L. & 00 & 00 & 16 & 6.06 \\
\hline \multicolumn{5}{|l|}{ Polygonaceae } \\
\hline Rumex crispus L. & 05 & 2.31 & 17 & 6.44 \\
\hline \multicolumn{5}{|l|}{ SOLANACEAE } \\
\hline Nicandra physalodes (L.) Gaertn. & 00 & 00 & 32 & 12.12 \\
\hline Salpichroa origanifolia (Lam.) Thell. & 00 & 00 & 00 & 00 \\
\hline Solanum lycopersicum $\mathrm{L}$. & 01 & 0.46 & 17 & 6.44 \\
\hline Solanum nigrum Linnaeus & 00 & 00 & 00 & 00 \\
\hline \multicolumn{5}{|l|}{ URTICACEAE } \\
\hline Urtica membranacea Poir. ex Savigny & 00 & 00 & 00 & 00 \\
\hline Total & 216 & 100 & 264 & 100 \\
\hline Species richness $(\mathrm{S})$ & 0.8 & - & 12 & - \\
\hline Diversity index (Shannon-Wiener H') & 0.9143 & - & 2.123 & - \\
\hline Equitability (Pielou J') & 0.4397 & - & 0.8543 & $3-$ \\
\hline Similarity (Simpson C) & 0.75 & - & - & - \\
\hline
\end{tabular}



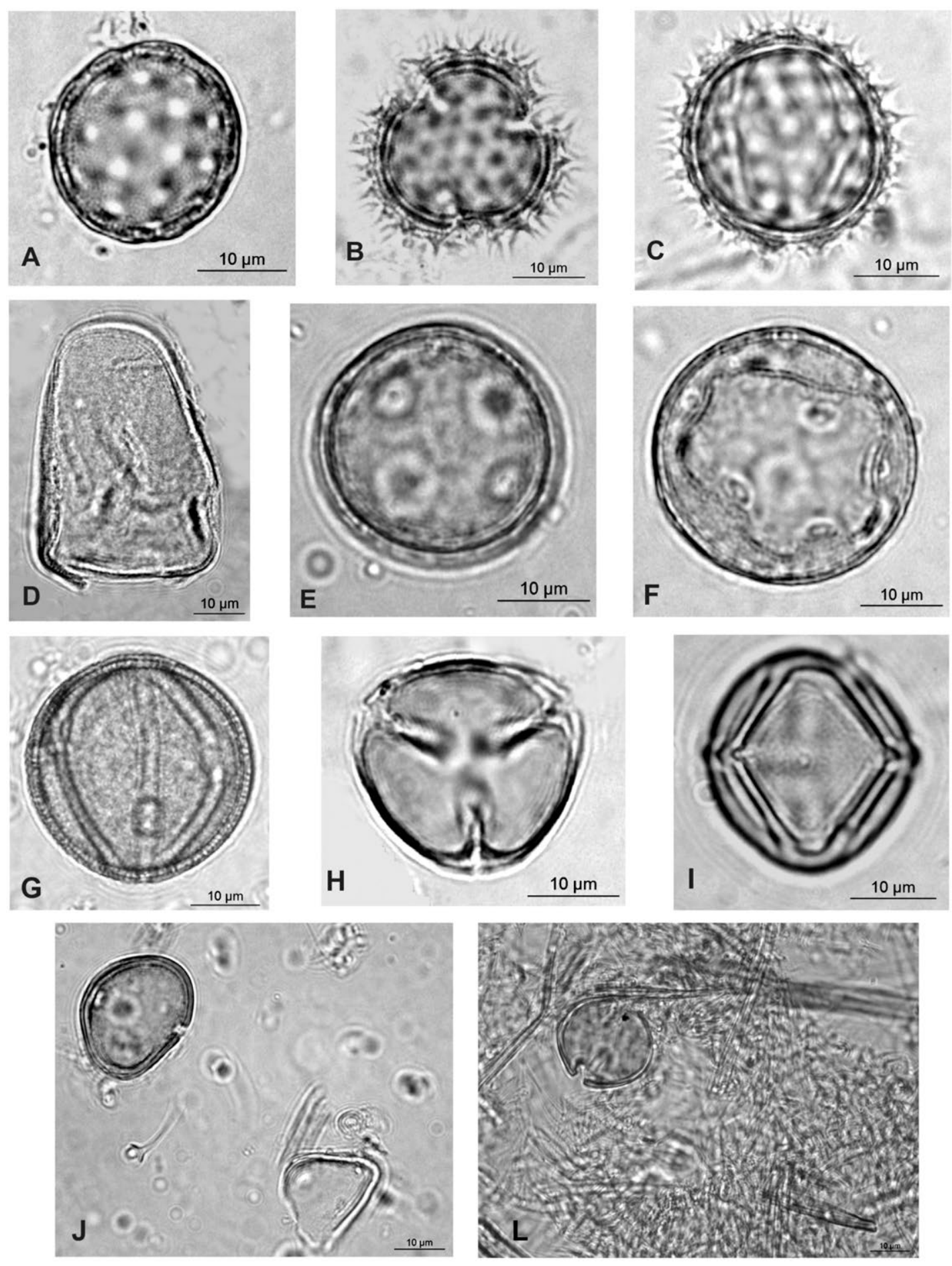

Fig. 1. The different types of pollen recorded in the guts of adults of Chrysoperla agilis Henry et al. (2003) (Neuroptera: Chrysopidae). (A) Chenopodium murale L. (Amaranthaceae), (B-C) Erigeron karvinskianus DC. (Asteraceae), (D) Cyperus rotundus L. (Cyperaceae), (E-F) Plantago lanceolata L. (Plantaginaceae), (G) Rumex crispus L. (Polygonaceae), (H-I) Solanum lycopersicum L. (Solanaceae), (J-L) Gut contents, with pollen of Plantago lanceolata.

vated fields (Schäfer, 2005; Silva et al., 2010). This distribution pattern may be favourable for lacewings, for these insects are more abundant in low altitude habitats (Mendes, 2011).

Pollen of Asteraceae, Plantaginaceae and Poaceae were the most frequently recorded in the gut contents of $C h$. agilis. Species of Poaceae are known to be important source of pollen for lacewings. Oliveira et al. (2009) describes how pollen of Poaceae improves the mass production of Chrysoperla externa (Hagen, 1861) (Neuroptera: Chrysopidae). More research is needed on the suitability of pollen from E. indica, Holcus lanatus L. and $P$. annua for the conservation and mass production of $C h$. agilis, since these species of plants were foraged by these insects, especially E. indica, which was characterized as accessory pollen in our quantitative analysis $(18.59 \%)$.

Pollen varies in its nutrient composition and may contain more than 14 different carbohydrates, and may be used as a source of energy and nutrients for protein synthesis in insects (Pannizi \& Parra, 1991). Nearly $60 \%$ of a pollen grain is 
made-up of highly digestible proteins that are easily assimilated by animals (Roulston \& Cane, 2000). It is thus probable that the greater variety of types of pollen eaten by $C h$. agilis in January means that a greater diversity of nutrients was available to it then that in December. According to Boregas et al. (2003), the physiology of these insects depends on the species composition of the pollen grains they feed on. Indeed, these authors intend to study the effects of different types of pollen on the reproductive fitness of Ch. agilis.

This study, which is based on the diversity of types of pollen recorded in gut contents, indicates that $C h$. agilis is a generalist when foraging for pollen. This should be considered when planning to promote the presence of lacewings in fields (Stelzl \& Devetak, 1999; Landis et al., 2000; Gurr et al., 2003). Villenave et al. (2006) suggest that the floristic composition of agricultural ecosystems has to be taken into account and that it should consist of corridors of species that flower at different times of the year, in order to provide beneficial insects with a perennial supply of food.

Of the three species of plants grown for food used in this study, only the pollen of tomato (S. lycopersicum) was eaten by the lacewings. This highlights the importance of maintaining a high plant biodiversity in the vicinity of crops, because even though they may not have a commercial value, they provide sources of food and cover for beneficial insects.

ACKNOWLEDGEMENTS. The authors would like to thank J. Xavier from the Departamento de Biologia at the Universidade dos Açores for letting us use the light microscope for photomicrography. The first author is the recipient of a postdoctoral grant (M3.1.7/F/024/2011) awarded by the Fundo Regional da Ciência (FRC), Governo dos Açores.

\section{REFERENCES}

Aspöck U., Plant J.D. \& NemeschKal H.L. 2001: Cladistic analysis of Neuroptera and their systematic position within Neuropterida (Insecta: Holometabola: Neuropterida: Neuroptera). - Syst. Entomol. 26: 73-86.

Boregas K.G.B., Carvalho C.F. \& Souza B. 2003: Aspectos biológicos de Chrysoperla externa (Hagen, 1861) (Neuroptera: Chrysopidae) em casa-de-vegetação. - Ciência Agrotec. 27: 7-16.

BozsiK A. 1992: Natural adult food of some important Chrysopa species (Plannipennia: Chrysopidae). - Acta Phytopatol. Entomol. Hung. 27: 141-146.

BROOKS S.J. \& BARNARD P.C. 1990: The green lacewings of the world: a generic review (Neuroptera: Chrysopidae). - Bull. Br. Mus. (Nat. Hist.) 59: 117-286.

Carvalho C.F. \& Souza B. 2000: Métodos de criação e produção de crisopídeos. In Bueno V.H.P. (ed.): Controle Biológico de pragas: Produção massal e controle de qualidade. Ufla, Lavras, pp. 91-110.

Erdtman G. 1952: Pollen Morphology and Plant Taxonomy of Angiosperms. Almqvist \& Wiksell, Stockholm, $539 \mathrm{pp}$

Freitas S. \& Penny N.D. 2001: The green lacewings (Neuroptera: Chrysopidae) of Brazilian agro-ecosystems. - Proc. Calif. Acad. Sci. 52: 245-395.

GurR G.M., Wratten S.D. \& Luna J.M. 2003: Multifunction agricultural biodiversity: Pest management and other benefits. - Basic Appl. Ecol. 4: 107-116.

Hammer Ø., Harper D.A.T. \& Ryan P.D. 2010: PAST - PAlaeontological STatistics. 31 pp. http://www.toyen.uio.no/ ohammer/past

LANDIS D.A., Wratten S.D. \& GurR G.M. 2000: Habitat management to conserve natural enemies of arthropod pests in agriculture. - Annu. Rev. Entomol. 45: 175-201.
MagurRan A.E. 2004: Measuring Biological Diversity. Blackwell Science, Oxford, 215 pp.

Mendes R.G. 2011: Neuroptera Communities of the Azores. Influence of the Habitat and Seasonality on the Distribution, Abundance and Dominance. Master Thesis, Universidade dos Açores, $56 \mathrm{pp}$.

Mendes R. \& Ventura M.A. 2010: Fitness of Chrysoperla agilis (Neuroptera: Chrysopidae) fed on different natural preys. In Devetak D., Lipovšek S. \& Arnett A.E. (eds): Proceedings of the 10th International Symposium on Neuropterology (22-25 June 2008, Piran, Slovenia). University of Maribor, Maribor, pp. 201-208.

NEW T.R. 2001: Introduction to the systematic and distribution of Coniopterygidae, Hemerobiidae and Chrysopidae used in pest management. In Mcewen P., New T.R. \& Whittington A.E. (eds): Lacewings in the Crop Environment. Cambridge University Press, Cambridge, pp. 6-28.

Oliveira S.A., Auad A.M., Souza B., Carvalho C.A., Souza L.S., Amaral R.L. \& Silva D.M. 2009: Benefícios do mel e pólen de forrageiras nos parâmetros biológicos de Chrysoperla externa (Hagen, 1861) (Neuroptera: Chrysopidae). Arq. Inst. Biol. 76: 583-588.

PANIzZI A.R. \& PARRA J.R.P. 1991: Ecologia nutricional de insetos e suas implicações no manejo de pragas. Manole, São Paulo, $359 \mathrm{pp}$.

Punt W., Hoen P.P., Blackmore S., Nilsson S. \& Le Thomas A. 2007: Glossary of pollen and spore terminology. - Rev. Palaeobot. Palynol. 143: 1-81.

Roulston T.H. \& CANe J.H. 2000: Pollen nutritional content and digestibility for animals. - Plant Syst. Evol. 222: 187-209.

SCHÄFER H. 2005: Flora of the Azores: A Field Guide. 2nd ed. Margraf/Backhuys, Weikersheim, $346 \mathrm{pp}$.

Silva L., Moura M., Schaefer H., Rumsey F. \& Dias E.F. 2010: Lista de plantas vasculares (Tracheobionta). In Borges P.A.V., Costa A., Cunha R., Gabriel R., Gonçalves V., Martins A.F., Melo I., Parente M., Raposeiro P., Rodrigues P., Santos R.S., Silva L., Vieira P. \& Vieira V. (eds): Listagem dos organismos terrestres e marinhos dos Açores, Principia, Cascais, pp. 117-146.

STElzL M. 1991: Untersuchungen zu Nahrungsspektren mitteleuropäischer Neuropteren-Imagines (Neuropteroidea, Insecta) mit einer Diskussion über deren Nützlichkeit als Opponenten von Pflanzenschädlingen. - J. Appl. Entomol. 111: 469-477.

Stelzl M. \& Devetak D. 1999: Neuroptera in agricultural ecosystems. - Agric. Ecosyst. Environ. 74: 305-321.

SunDBY R.A. 1967: Influence of food on the fecundity of Chrysopa carnea Stephens (Neuroptera, Chrysopidae). Entomophaga 12: 475-479.

Ventura M.A., Thierry D. \& Coderre D. 2005: Origins and composition of the "Chrysoperla carnea complex" (Neuroptera: Chrysopidae) in the Azores and Madeira islands In Leyens T. (ed.): Proceedings of the IV Symposium Fauna and Flora of the Atlantic Islands, Praia, Cabo Verde, 9-13 Setember 2002. Ministério do Ambiente, Agricultura e Pescas, Praia, Cabo Verde, pp. 135-141.

Venzon M., Rosado M.C., Euzébio D.E., Souza B. \& SchoEREDER J.H. 2006: Suitability of leguminous cover crop pollens as food source for the green lacewing Chrysoperla externa (Hagen) (Neuroptera: Chrysopidae). - Neotrop. Entomol. 35: 371-376.

Villenave J., Deutsch B., Lodé T. \& Rat-Morris E. 2006: Pollen preference of the Chrysoperla species (Neuroptera: Chrysopidae) occurring in the crop environment in western France. - Eur. J. Entomol. 103: 771-777.

ZANDER E. 1935: Beitraege zur Herkunftsbestimmung bei Honig. I. Reichsfachgruppe Imker E.V., Berlin, 343 pp. 